\title{
KOMPLEKSNOST KAO NOSILAC PREFERENCIJA I INDIKATOR POSJEĆENOSTI PARKOVA
}

\author{
COMPLEXITY AS A DETERMINANT OF PREFERENCE \\ AND A PREDICTOR OF PARK VISITATIONS
}

\author{
Petra Pereković i Branka Aničić
}

\section{SAŽETAK}

Članak istražuje određene aspekte značenja i konceptualizacije fenomena kompleksnosti kao složene cjeline senzacija koje pridonose uspješnosti otvorenih prostora. Problematika rada obuhvatila je kritičko preispitivanje definiranja i dimenzija procjenjivanja složenosti otvorenih prostora te preispitivanje indikatora „optimalne razine složenosti“ parkova. Rad je uključio kombiniranje tri metode - strukture analize složenosti, metodu opservacije uz metodu brojanja te anketiranje. Metode su primijenjene na istom području rada - dva suvremena parka, a korisnici tih parkova našli su se u trojnoj ulozi - kao objekt promatranja i metode brojanja te kao ispitanici u anketnoj metodi. Provedeno istraživanje jasno ukazuje na to da je koncept složenosti važna komponenta uspješnosti parkova te da su složeniji dijelovi parkova posjećeniji i više cijenjeni od onih manje složenih. Također, pokazalo se da je za cjelovito praćenje kompleksnosti otvorenih prostora potrebno okupljati i vizualne i funkcionalne indikatore složenosti kao i dinamične dimenzije složenosti otvorenih prostora. Pri tome smatramo, a i rezultati tako govore, da je kod oblikovanja otvorenih prostora stanje velike složenosti optimalnije od stanja srednje ili male složenosti parkova.

Ključne riječi: kompleksnost, park, dimenzije kompleksnosti, preferencije

\section{ABSTRACT}

This paper critically questions the way landscape complexity is defined and the dimensions of its assessment. Its goal is to help develop a more sophisticated assessment of the levels of landscape complexity and to define basic groups of indicators to determine what could be considered the "optimal degree of complexity". The research combined three methods: the observational method, the counting method and survey research. The conducted research 
shows that high complexity is more suitable than low complexity in the design of parks for recreational use. The results have also shown that to fully evaluate complexity it is necessary to consider both visual and functional indicators of the complexity of parks as well as some of their dynamic dimensions.

Keywords: Complexity, park, dimensions of complexity, preference

\section{UVOD}

Kompleksnost krajobraza ubraja se u jedno od najčešćih područja istraživanja percepcije krajobraza. U posljednje vrijeme postoje sugestije širenja opsega sagledavanja kompleksnosti kao i dimenzija njezina procjenjivanja, definiranja i metoda kojima se istražuje. Stoga je fokus ovog rada usmjeren na preispitivanje koncepta složenosti u nekoliko problemskih kategorija. To su: kritičko preispitivanje definiranja i procjenjivanja složenosti krajobraza; utvrđivanje "koliko je složen krajobraz dovoljno složen krajobraz?"; te procjenjivanje pridonose li svi elementi krajobraza u jednakoj mjeri percepciji složenosti. Budući da je jedan od temeljnih ciljeva oblikovanih krajobraza (parkova, stambenog zelenila i sl.) da što više služe potrebama korisnika, koncept kompleksnosti je jedan od čimbenika koji može doprinositi njihovoj uspješnosti. Pri tome, možemo kreirati krajobraz koji je niskokompleksan ili visokokompleksan, a takav percepcijski može biti više ili manje privlačan njegovim korisnicima ili promatračima kao i razlog njegova smanjena ili povećana korištenja.

\section{Dosadašnja istraživanja kompleksnosti krajobraza}

Na prvi pogled, dosadašnje definiranje kompleksnosti u području krajobrazne arhitekture je ujednačeno te se najčešće odnosi na broj i raznolikost elemenata nekog krajobraza. Najšire upotrebljavana definicija kompleksnosti vezana je uz "teoriju informacijskih varijabli" koju su razvili Kaplanovi (1998., 1989.). U toj se teoriji kompleksnost definira kao količina drukčijih vizualnih elemenata ili bogatstvo neke „scene“ a takvo su definiranje kompleksnosti prihvatili mnogi istraživači. Primjerice, Herzog i Bryce (2007.) kompleksnost razmatraju kroz pitanja "koliko se toga događa na sceni" i "koliko je scena vizualno bogata". Tveit i sur. (2006.) definiraju kompleksnost kao "diverzitet i bogatstvo elemenata i obilježja..." dok je Nasar (1994.) promatra kao diverzitet i vizualno bogatstvo krajobraza. Pri tome Stamps (2004.) navodi da je u zadnjih 30 godina 
eksperimentalna literatura, prema njegovim spoznajama, objavila šezdesetak radova u kojima se istraživači koriste istim operacijskim definicijama „informacijskih varijabli“ (i kompleksnosti) uz vrlo male modifikacije.

Ipak, u posljednje vrijeme koncept kompleksnosti smatra se „složenijim“ pitanjem nego što se dosada smatralo. Zamjetno je da iako postoji ujednačeno definiranje kompleksnosti, uglavnom se ono odnosi na vizualno bogatstvo elemenata krajobraza a zanemaruju se drugi aspekti kompleksnosti kao što su funkcionalna kompleksnost te dinamične ili temporalne dimenzije složenosti otvorenih prostora. Pri tome, vizualna složenost se odnosi na skup elementa koje u otvorenom prostoru prvenstveno doživljavamo kao vizualne stimulanse (cvjetne gredice, fontane, biste, itd.) a funkcionalna složenost se odnosi na skup elementa koji osim vizualnog značenja imaju jednu ili više funkcionalnih uloga. Funkcionalne uloge mogu biti vrlo raznolike a nosioci su im elementi s jednom ili više namjena (sprave za igru, sprave za vježbanje, sportski teren, muzička sprava, ,zid“ za crtanje i mnogobrojni drugi elementi rekreacijske namjene, kreativnog izražavanja, zabave i sl.). Osim toga, kompleksnost se u krajobrazu može odnositi i na dinamične dimenzije složenosti odnosno na sve promjene koje se u određenom vremenskom periodu pojavljuju u vezi s njegovim elementima a pridonose raznolikosti vizualnog doživljavanja ili funkcionalnog korištenja. To mogu biti promjene određenih karakteristika krajobraznih elemenata (npr. sezonske promjene bilja poput cvatnje), promjene funkcije ili višefunkcionalnost elemenata (vodena površina koja ljeti služi za kupanje ili kao element vizualnog doživljavanja a zimi služi za klizanje), nefiksirani elementi (dinamika vezana za mogućnost promjene pozicije a samim time i namjene elementa), privremeni elementi i događanja $u$ krajobrazu (manifestacije, izložbeni panoi i dr.) i sl. Stoga se svaki krajobraz može gledati i kroz vizualne ali i kroz funkcionalne te dinamične indikatore kompleksnosti koji tek zajednički čine neki krajobraz više ili manje kompleksnim.

Na neke neujednačenosti prilikom istraživanja koncepta složenosti ukazuju i drugi istraživači. Tveit i sur. (2006.) napominju da se pri istraživanjima rabe drukčije forme kompleksnosti te da je malo studija koje se fokusiraju na to od čega se zapravo sastoji kompleksnost te koji elementi najviše pridonose kompleksnosti krajobraza. Ode i sur. (2010.) problematiku istraživanja vide u širokom nizu indikatora složenosti koji se koriste te nedostatku jake teorijske baze za primjenu i analizu modela složenosti. Smatraju važnim identificirati tipove kompleksnosti koji se mogu primijeniti na neki fenomen te pronalaženje odgovarajućih metoda njihove prostorne analize. Jedan od izazova istraživanja 
vide i u integraciji disciplina koje se bave doživljavanjem ljudi i onih koji su koncentrirani na kalkulacije krajobraznih podataka iz 2D prostornih prikaza. Ewing i sur. (2005.) napominju da se $\mathrm{u}$ istraživanjima često ne mjere isti indikatori kompleksnost a Nasar (2008.) ističe da varijante artefakata koji se istražuju mogu ometati i rezultate dobivene istraživanjima. I Papadimitriou (2002.) napominje da kompleksnost još nije definirana na „pravi“ način kao ni jednoznačna metoda njezine kalkulacije pri čemu nastaju nedoumice zbog toga što primjerice, jedan strukturno kompleksan krajobraz istodobno može biti i slabo funkcionalan (male funkcionalne složenosti). Takvo promišljanje posebice je važno za urbane otvorene prostore jer su oni, između ostalog, namijenjeni i različitim funkcijama na otvorenom, a u tom kontekstu, mogu istovremeno biti strukturno bogati, s mnogo raznolikih vizualnih elemenata (visoka vizualna složenost), ali istodobno i slabo funkcionalni (mala funkcionalna složenost). S tim u vezi smatramo da se i stanje krajobrazne složenosti (velika ili mala složenost, vizualna ili funkcionalna složenost) može promatrati u kontekstu stvaranja više ili manje potencijalnih okoliša i prostornih prilika. Pritom bi povećana vizualna složenost krajobraza mogla voditi ka korisniku koji je više pasivni promatrač, a funkcionalna raznolikost, čemu i ovo istraživanje ide u prilog, ka korisniku koji aktivno participira u parkovnom događanju.

$\mathrm{Na}$ kraju, sve češće se napominje da je većina dosadašnjih istraživanja kompleksnosti dobivena metodama procjene fotografskog materijala kao i to da se često ispituje samo vizualna složenost krajobraza. Smatra se kako nedostaju rezultati istraživanja realnih prostora te funkcionalne složenosti krajobraza (Purcell i sur., 2001; Palmer, 2003; Aspinall i sur., 2007.). Pritom Heft (2007.) napominje da je važno da su u istraživanjima ljudi participatori, a ne samo "promatrači" krajobraza (fotografija i simuliranih krajobraza) te zagovara "dinamički" sustav promatranja krajobraza koji uključuje primjećivanje i onog što krajobraz korisniku pruža za „djelovanje“ (koncept prostorne "priuštivosti"). Zbog svih navedenih razloga fokus ovog rada usmjeren je bio na redefiniranje kompleksnosti otvorenih prostora te primjene metode istraživanja koje će uključiti novije sugestije istraživača.

\section{Definiranje kompleksnosti otvorenih prostora}

U ovome radu, kompleksnost je definirana kao količina i raznolikost strukturnih elemenata otvorenih prostora uključujući sve elemente vizualnog i funkcionalnog karaktera koji se pojavljuju u građi nekog prostora. Nisko kompleksan krajobraz je onaj koji stvara dojam previše jednostavnog 
(,ispražnjenog“) krajobraza kao posljedice malog broja i/ili raznolikosti elemenata, a visoko kompleksni krajobrazi su oni koji odaju dojam prenatrpanosti kao posljedicu velikog broja i/ili raznolikosti elemenata. Složenijim krajobrazom smatramo i onaj koji sadrži više elemenata $\mathrm{s}$ mnogostrukom namjenom ili mogućim funkcijama te izraženim dinamičnim (temporalnim) promjenama, u odnosu na krajobraz koji ima istu količinu elemenata ali s jednom ili manjim brojem potencijalnih namjena ili primjena. Također, ako neka dva krajobraza sadrže jednako elemenata, a jedan od njih ima izražene neke temporalne promjene, tad on pruža potencijalno više elemenata za doživljavanje i iskazuje veću kompleksnost.

\section{METODE RADA}

Za potrebe ovog rada kombinirano je nekoliko različitih metoda - strukturne analize, opservacije terena uz metodu brojanja te anketiranje. Kombiniranje metoda provedeno je kako bi se koncept složenosti istražio kroz paralelnu analizu fizičke složenosti te percipirane složenosti i to od eksperta (stručna analiza) te njegovih promatrača i korisnika. Pri tome su akceptirane i neke sugestije istraživača koje se mogu očitati na sljedeći način: ispitivani krajobrazi istovjetni su kroz cjelokupno istraživanje (sve tri metode provedene su na istom području rada odnosno na istovjetnom otvorenom prostoru), obuhvaćen je ekspertni i percepcijski baziran pristup pri procjenjivanju kompleksnosti (stručna ili ekspertna procjena, procjena korisnika i bihevioralno mjerenje), te je osim vizualne složenosti istražena i funkcionalna te dinamična dimenzija kompleksnosti. Za područje rada odabrani su gradski parkovi jer su to javni otvoreni prostori koji uključuju široki raspon korištenja i korisnika a te im karakteristike omogućavaju i vrlo veliku složenost u oblikovanju. U tu svrhu izdvojeni su park Bundek (Zagreb) i Park Franje Tuđmana (Velika Gorica), primjeri suvremenih gradskih parkova. U svakom su parku izdvojene tvz. "lokacije" - točno određene površine parka koje oblikuju smislenu prostornu cjelinu pri čemu je svaka lokacija nosilac određenog stupnja kompleksnosti. Procjena složenosti izdvojenih lokacija provedena je putem strukturnih analiza (stručna procjena) odnosno raščlanjivanjem krajobraza na njegove sastavne dijelove - elemente. Na temelju ukupnog broja izdvojenih elemenata (brojnost $\mathrm{i}$ raznolikost elemenata) vršila se procjena složenosti svake od lokacija (visoka, niska i srednja kompleksnost) pri čemu se prihvaćala i vrsta elemenata koji čine određenu lokaciju (prevladavanje funkcionalnih ili vizualnih elemenata). 
Petra Pereković i sur.: Kompleksnost kao nosilac preferencija i indikator posjećenosti parkova

Metoda brojanja provela se bilježenjem broja korisnika na različito kompleksnim lokacijama parkova (mala, srednja i velika kompleksnost) pri čemu se utvrdila brojnost korisnika odnosno intenzitet posjećivanja različito kompleksnih dijelova parkova. Takvo bilježenje provelo se promatranjem i fotografiranjem različito kompleksnih lokacija te izravnim i naknadnim prebrojavanjem broja korisnika koji su se zatekli na određenoj lokaciji. Primjenom metode brojanja korisnika parkova pokušalo se utvrditi utječe li različiti stupanj složenosti izdvojenih lokacija parkova na njihovu posjećenosti. Tako su se i dobili odgovori na pitanje koliko je intenzitet korištenja parkova uvjetovan razlikom postojanja funkcionalnih i vizualnih elemenata sadržanih u njihovoj građi (promatrane lokacije iskazivale su veći ili manji broj vizualnih odnosno funkcionalnih elemenata).

Metoda opservacije (bihevioralno promatranje) nadovezalo se na metodu brojanja jer se temeljila na istom radnom postupku. Ovaj dio istraživanja odnosio se na primijećene aktivnosti, brojnost i promjene ponašanja korisnika na lokacijama vezane za neke dinamične dimenzije složenosti kao posljedica unosa, prenošenja, promjena, nestanka ili drugih dinamičnih "događanja" u parkovima ili su bile posljedica dinamičnih karakteristika elemenata u parkovima (aktivnosti vezane za pomične odnosno nefiksirane elemente, aktivnosti vezane za višefunkcionalne elemente). $U$ tu svrhu, bilježile su se aktivnosti i interakcija korisnika s raznolikim dinamičnim elementima parkova.

U svrhu provođenja obje metode, parkovi su posjećivani u četveromjesečnom vremenskom kontinuitetu (od lipnja do rujna 2010. godine), a obilasci terena obavljali su se istovremeno u oba parka svaki drugi tjedan od početka promatranja, a svaki se dan u promatranom tjednu teren obilazio dva puta - prijepodne od 10 do 11.30 sati te poslijepodne od 17.30 do 19 sati. Od ukupno 224 planirana obilaska terena obavljeno je njih 192. Ostalih dana teren nije bio posjećen zbog vremenskih uvjeta (izostanak značajnog broja korisnika zbog kišovitog vremena). U periodu provođenja ovih metoda proizvedeno je i anketno istraživanje.

Konceptualizacija anketnog istraživanja okupila je tri grupe pitanja - osobni podaci o ispitanicima te pitanja o tome kako često ispitanici posjećuju park te koji je najčešći razlog posjeta. Druga skupina pitanja obuhvatila je stav ispitanika o tome treba li povećati broj sadržaja u parku, koji su to elementi čija bi se količina eventualno trebala povećati te u koji bi se dio parka takve elemente trebalo smjestiti. Specifičnost ovog pitanja sastojala se u tome da su predloženi dijelovi 
parkova za smještanje elemenata zapravo predstavljale „lokacije“ različitog stupnja kompleksnosti izdvojene i korištene u ostalim metodama ovog istraživanja. Treća skupina pitanja bila je vezana uz procjenjivanje različito složene četiri scene parkova - dvije pozicije parka Bundek te dvije pozicije parka Velika Gorica. Svaka od tih četiriju scena predstavljena je putem niza od pet fotografija. Pritom je srednja fotografija niza (3) predstavlja postojeće stanje a ostale su fotografije simulirana stanja povećavanja ili smanjivanja složenosti. Time se složenosti stupnjevala u kategorije složenosti - vrlo mala (1), mala (2), srednja (3), velika (4) i vrlo velika (5). Stoga, gledajući cijeli niz fotografija (1-5) pokušalo se stvoriti ujednačeno stupnjevanje povećanja odnosno smanjivanja kompleksnosti i to tako da nijedna fotosimulacija slijeda drastično ne odskače prema broju ili raznolikosti elemenata u usporedbi s prethodnom odnosno sljedećom fotografijom niza. Time su zapravo uspoređivane iste scene krajobraza koje variraju jedino prema stupnju složenosti (vidi niz fotografija 1) te je izbjegnuto variranje drugih varijabli koje bi mogle utjecati na prosudbe ispitanika, a mogle bi se pojaviti uspoređivanjem različitih scena krajobraza (različiti stupanj „prirodnosti“, različiti elementi scene i sl.). Anketiranje je provedeno u rujnu 2010. u parkovima Bundek i Velika Gorica. Izbor ispitanika je bio slučajan, a anketiranje je provedeno putem unaprijed pripremljenoga anketnog upitnika $u$ izravnom kontaktu s ispitanicima na prigodnome ujednačenom komparativnom uzorku. Anketirana je ukupno 301 osoba (150 u parku Velika Gorica i $151 \mathrm{u}$ parku Bundek).

\section{Rezultati strukturne analize promatranih parkova - odabir „lokacija“}

U parku Velika Gorica stukturnim analizama je izdvojeno šest lokacija čime je park obuhvaćen u cijelosti. Svaka od izabranih lokacija parka činila je logičnu prostornu cjelinu a raspon izdvojenih elemenata na lokacijama iznosio je 5-11 (5 - najmanje složena lokacija, 11 - najviše složena lokacija parka). Variranje funkcionalnih elemenata iznosilo je 2 do 3 funkcionalna elementa po lokaciji. Park Bundek se zbog njegove velike površine prvotno podijelio u tri dijela različitog stupnja kompleksnosti. Najkompleksniji, središnji dio parka Bundek sadrži ukupno 25 različitih elemenata i relativno velik udio funkcionalnih elemenata u odnosu na druge dvije cjeline parka. Drugi, zapadni dio čini uređenje manjeg broja i raznolikosti elemenata (13) uz prevladavanje elemenata vizualnoga karaktera, dok treći, istočni dio parka je prostor najmanje složenosti (5) i sadrži samo elementarne strukture prostornog uređenja. Imajući to u vidu, za park Bundek izdvojena je ukupno 21 lokacija - 8 lokacija predstavlja najsloženiji dio, 8 lokacija srednje složen, te 6 lokacija najmanje složeni dio parka. 
Petra Pereković i sur.: Kompleksnost kao nosilac preferencija i indikator posjećenosti parkova

Tablica 1. Promatrane lokacije rangirane prema ukupnom broju zabilježenih korisnika Velika Gorica

Table 1 Observed locations rated according to the total number of registered users Velika Gorica

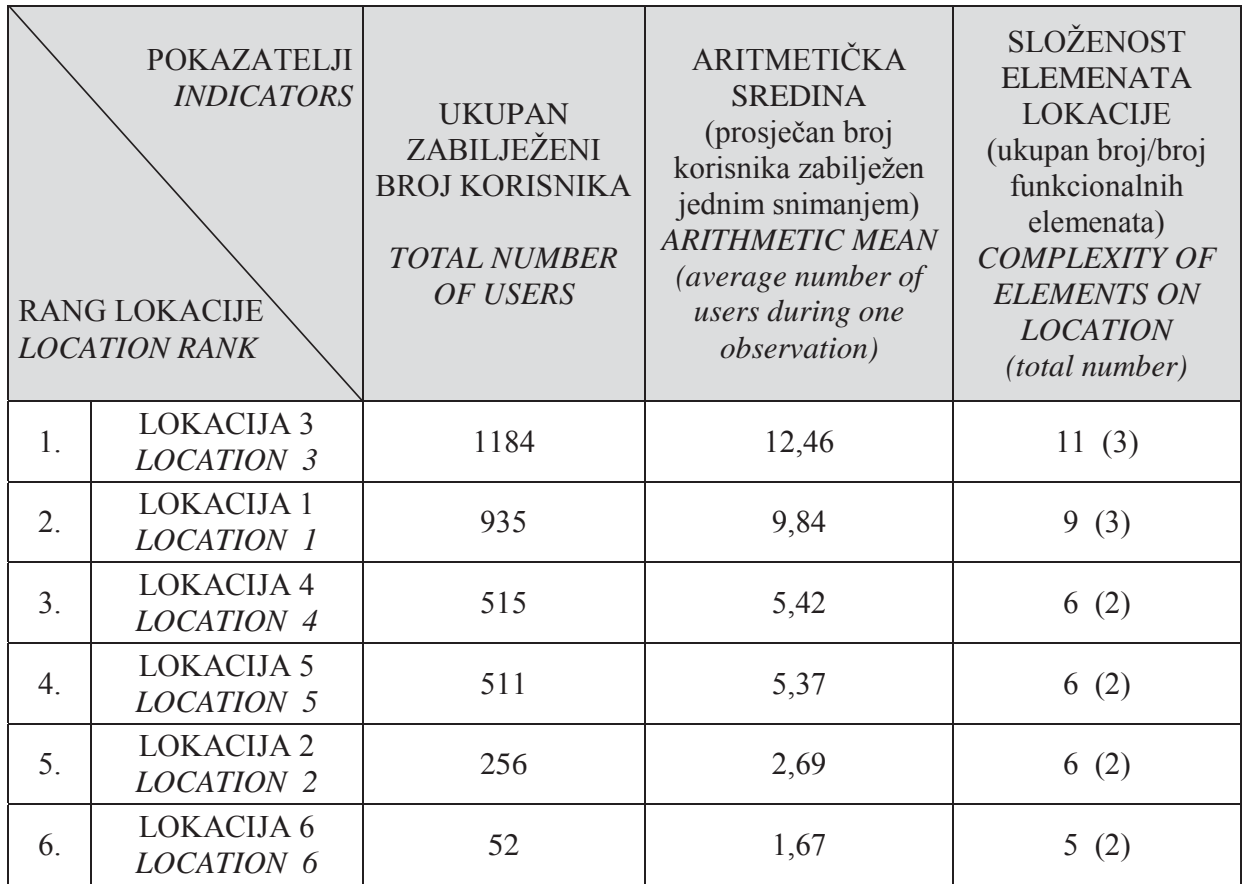

\section{Rezultati bilježenja broja korisnika u različito kompleksnim dijelovima parkova}

Park Velika Gorica obiđen je 95 puta a tijekom obilazaka terena ukupno je zabilježeno 3,453 korisnika. Pokazatelji govore da je od ukupnog broja zabilježenih korisnika, najveći broj njih zabilježen na najkompleksnijim lokacijama parka (tablica i grafikon 1). Također je vidljivo da se sa smanjenjem složenosti smanjuje i posjećenost lokacija. Pritom je više od polovice zatečenih korisnika zabilježeno na dvije najkompleksnije lokacije parka (61\%), a na najmanje kompleksnoj lokaciji zabilježeno je samo $2 \%$ od ukupnog broja posjetitelja. S obzirom na izlazne rezultate, možemo zaključiti da je najveća posjećenost onih lokacija koje imaju najviše kompleksnih elemenata, a najmanja je posjećenost zabilježena u najmanje kompleksnim dijelovima parka. 
Petra Pereković i sur.: Kompleksnost kao nosilac preferencija i indikator posjećenosti parkova

Usporedimo li vezu intenziteta posjećenosti i kompleksnosti promatranih lokacija s nekim drugim parametrima (doba dana, vremenski uvjeti i pojedinačni mjeseci promatranja), uvidjet ćemo da se redoslijed lokacija znatno ne mijenja. Usporedimo li pak lokacije 4, 5 i 2 koje iskazuju jednaku kompleksnost elemenata, uvidjet ćemo da se, iako imaju jednak broj elemenata, razlikuju prema posjećenosti. Takve razlike mogu se povezati s građom elemenata koji čine promatrane lokacije unutar čega smatramo da je karakteristika višefunkcionalnosti elemenata lokacija 4 i 5 imala presudnu ulogu za zabilježenu povećanu posjećenost. $\mathrm{Na}$ lokaciji 4 je modelacija terena koja se pojavila kao generator aktivnosti sjedenja, igre, vidikovca, pružanja hladovine, poligona za vožnju bicikla, rastrčavanje pasa i sl., a skulptura na lokaciji 5 se vrlo često koristi za igre loptom - postolje i prostor oko skulpture koristi se kao gol i ploha za različite igre loptom a sama skulptura katkad i kao sprava za penjanje djece. Za razliku od toga lokacija 2 sadrži u većem dijelu vizualne elemente koji nisu generirali neka višestruka i raznolika korištenja te duže zadržavanje ili okupljanje korisnika (šetnja i sjedenje na klupama pretežne su aktivnosti na toj lokaciji).

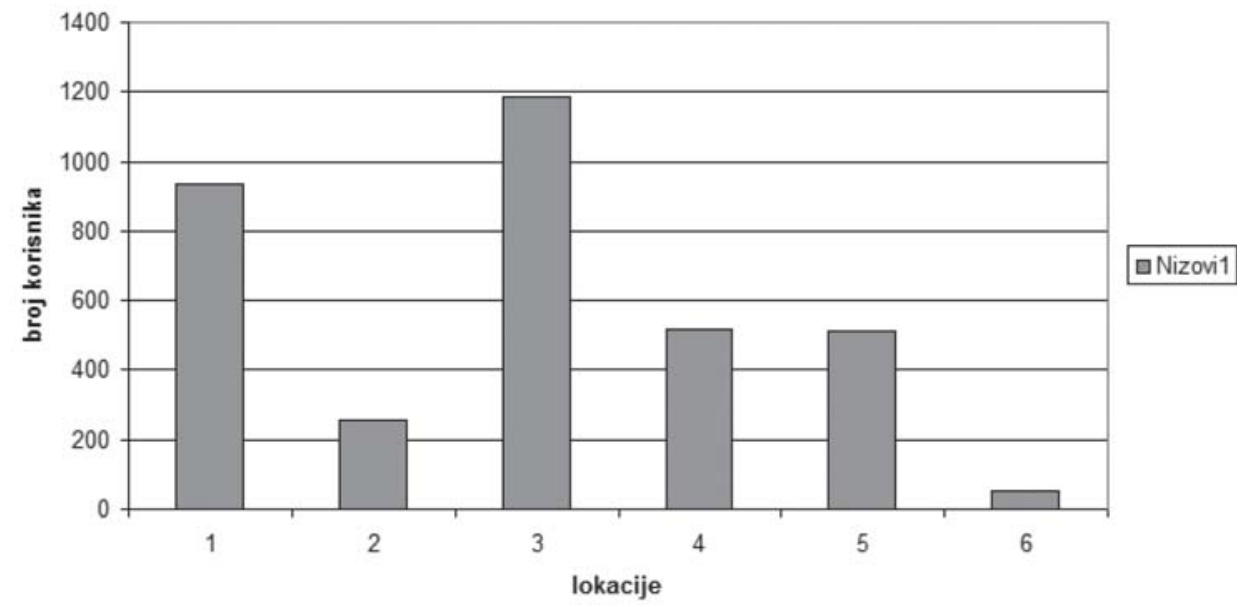

Grafikon 1. Ukupan broj zatečenih korisnika na lokacijama parka Velika Gorica Graph 1 Observed locations rated according to the total number of registered users Velika Gorica 
Petra Pereković i sur.: Kompleksnost kao nosilac preferencija i indikator posjećenosti parkova

Park Bundek ukupno je obiđen 97 puta a tijekom obilazaka terena ukupno je zabilježeno 16,239 korisnika. Od tog broja, najviše je korisnika zabilježeno na lokacijama središnjeg dijela parka koji je ujedno njegov najsloženiji dio. Lokacije zapadnog i istočnog dijela parka izrazito su manje posjećene. Pokazatelji ukupne posjećenosti promatranih lokacija zajedno s kompleksnošću lokacija prikazani su u tablici i grafikonu 2. Iskažemo li posjećenost lokacija zajednički za svaki od tri izdvojena dijela parka, dobit ćemo rezultat da je u središnjemu, najsloženijem dijelu parka zabilježeno $80.9 \%$, u zapadnom dijelu parka zabilježeno je $12,7 \%$ posjetitelja, a u istočnome, najmanje složenom dijelu samo 6,4\%. Usporedimo li dobivene rezultate prema drugim parametrima (posjećenosti prijepodne i poslijepodne, za sunčanih odnosno oblačnih dana ili prema pojedinim mjesecima promatranja) uvidjet ćemo da su rezultati vrlo slični navedenima. Rezultati posjećenosti zapadnog $i$ istočnog dijela parka pokazali su se suprotni predviđenima - pretpostavljalo se da će zapadni dio parka, koji je složeniji, imati znatno višu razinu posjećenosti nego što su pokazali rezultati. Mogućim razlogom smatramo korištenje istočnog dijela parka za šetnju i istrčavanje pasa, što je ujedno najčešća aktivnost u tom dijelu parka dok je u ostalim dijelovima parka zabranjena ta aktivnost. Osim toga, važno je napomenuti i to da zapadni dio parka ponajprije čine vizualni elementi, što također može utjecati na njegovu smanjenu korištenost $\mathrm{u}$ odnosu na središnji dio parka, odnosno na ujednačenu korištenost $\mathrm{s}$ istočnim dijelom, koji također sadrži uglavnom vizualne elemente.

Tablica 2. Promatrane lokacije rangirane prema ukupnom broju zabilježenih korisnika Bundek

Table 2 Observed locations rated according to the total number of registered users Bundek

\begin{tabular}{|c|c|c|c|c|}
\hline \multicolumn{2}{|c|}{$\begin{array}{r}\text { POKAZATELJI } \\
\text { INDICATORS }\end{array}$} & $\begin{array}{c}\text { UKUPAN } \\
\text { ZABILJEŽENI } \\
\text { BROJ } \\
\text { KORISNIKA } \\
\\
\text { TOTAL } \\
\text { NUMBER OF } \\
\text { USERS }\end{array}$ & $\begin{array}{l}\text { ARITMETIČKA } \\
\text { SREDINA } \\
\text { (prosječan broj } \\
\text { korisnika } \\
\text { zabilježen jednim } \\
\text { snimanjem) } \\
\text { ARITHMETIC } \\
\text { MEAN } \\
\text { (average number } \\
\text { of users during }\end{array}$ & $\begin{array}{c}\text { SLOŽENOST } \\
\text { ELEMENATA } \\
\text { LOKACIJE } \\
\text { (ukupan broj elemenata) } \\
\text { COMPLEXITY OF } \\
\text { ELEMENTS ON } \\
\text { LOCATION } \\
\text { (total number of elements) }\end{array}$ \\
\hline 1. & $\begin{array}{l}\text { LOKACIJA / } \\
\text { LOCATION } 2\end{array}$ & 3321 & 34,59 & $\begin{array}{l}26 \text { središnji dio / } \\
\text { central area }\end{array}$ \\
\hline 2. & $\begin{array}{l}\text { LOKACIJA / } \\
\text { LOCATION } 4\end{array}$ & 2453 & 25,55 & $\begin{array}{l}26 \text { središnji dio / } \\
\text { central area }\end{array}$ \\
\hline
\end{tabular}


Petra Pereković i sur.: Kompleksnost kao nosilac preferencija i indikator posjećenosti parkova

\begin{tabular}{|c|c|c|c|c|}
\hline 3. & $\begin{array}{l}\text { LOKACIJA / } \\
\text { LOCATION } 3\end{array}$ & 1790 & 18,64 & $\begin{array}{c}26 \text { središnji dio / } \\
\text { central area }\end{array}$ \\
\hline 4. & $\begin{array}{l}\text { LOKACIJA / } \\
\text { LOCATION } 8\end{array}$ & 1704 & 17,75 & $\begin{array}{c}26 \text { središnji dio / } \\
\text { central area }\end{array}$ \\
\hline 5. & $\begin{array}{l}\text { LOKACIJA / } \\
\text { LOCATION } 1 \\
\end{array}$ & 1270 & 13,22 & $\begin{array}{c}26 \text { središnji dio / } \\
\text { central area }\end{array}$ \\
\hline 6. & $\begin{array}{l}\text { LOKACIJA / } \\
\text { LOCATION } 7\end{array}$ & 1241 & 12,92 & $\begin{array}{c}26 \text { središnji dio / } \\
\text { central area }\end{array}$ \\
\hline 7. & $\begin{array}{l}\text { LOKACIJA / } \\
\text { LOCATION } 6\end{array}$ & 1144 & 11,91 & $\begin{array}{c}26 \text { središnji dio / } \\
\text { central area }\end{array}$ \\
\hline 8. & $\begin{array}{l}\text { LOKACIJA / } \\
\text { LOCATION } 16\end{array}$ & 433 & 4,5 & $\begin{array}{c}13 \text { zapadni dio / } \\
\text { western area }\end{array}$ \\
\hline 9. & $\begin{array}{l}\text { LOKACIJA / } \\
\text { LOCATION } 9 \\
\end{array}$ & 340 & 3,54 & $\begin{array}{c}13 \text { zapadni dio / } \\
\text { western area }\end{array}$ \\
\hline 10. & $\begin{array}{l}\text { LOKACIJA / } \\
\text { LOCATION } 20\end{array}$ & 315 & 3,28 & $\begin{array}{l}5 \text { istočni dio / } \\
\text { eastern area }\end{array}$ \\
\hline 11. & $\begin{array}{c}\text { LOKACIJA / } \\
\text { LOCATION } 10 \\
\end{array}$ & 298 & 3,10 & $\begin{array}{c}13 \text { zapadni dio / } \\
\text { western area }\end{array}$ \\
\hline 12. & $\begin{array}{l}\text { LOKACIJA / } \\
\text { LOCATION } 13\end{array}$ & 284 & 2,95 & $\begin{array}{c}13 \text { zapadni dio / } \\
\text { western area }\end{array}$ \\
\hline 13. & $\begin{array}{c}\text { LOKACIJA / } \\
\text { LOCATION } 15\end{array}$ & 265 & 2,76 & $\begin{array}{c}13 \text { zapadni dio / } \\
\text { western area }\end{array}$ \\
\hline 14. & $\begin{array}{c}\text { LOKACIJA / } \\
\text { LOCATION } 18\end{array}$ & 228 & 2,37 & $\begin{array}{l}5 \text { istočni dio / } \\
\text { eastern area }\end{array}$ \\
\hline 15. & $\begin{array}{c}\text { LOKACIJA / } \\
\text { LOCATION } 21\end{array}$ & 221 & 2,30 & $\begin{array}{l}5 \text { istočni dio / } \\
\text { eastern area }\end{array}$ \\
\hline 16. & $\begin{array}{l}\text { LOKACIJA / } \\
\text { LOCATION } 5\end{array}$ & 206 & 2,14 & $\begin{array}{c}26 \text { središnji dio / } \\
\text { central area }\end{array}$ \\
\hline 17. & $\begin{array}{l}\text { LOKACIJA / } \\
\text { LOCATION } 14\end{array}$ & 193 & 2,01 & $\begin{array}{c}13 \text { zapadni dio / } \\
\text { western area }\end{array}$ \\
\hline 18. & $\begin{array}{c}\text { LOKACIJA / } \\
\text { LOCATION } 19\end{array}$ & 168 & 1,75 & $\begin{array}{l}5 \text { istočni dio / } \\
\text { eastern area }\end{array}$ \\
\hline 19. & $\begin{array}{l}\text { LOKACIJA/ } \\
\text { LOCATION } 11\end{array}$ & 165 & 1,71 & $\begin{array}{c}13 \text { zapadni dio / } \\
\text { western area }\end{array}$ \\
\hline 20. & $\begin{array}{l}\text { LOKACIJA / } \\
\text { LOCATION } 17\end{array}$ & 115 & 1,19 & $\begin{array}{l}5 \text { istočni dio / } \\
\text { eastern area }\end{array}$ \\
\hline 21. & $\begin{array}{l}\text { LOKACIJA / } \\
\text { LOCATION } 12\end{array}$ & 85 & 0,88 & $\begin{array}{c}13 \text { zapadni dio / } \\
\text { western area }\end{array}$ \\
\hline
\end{tabular}


Petra Pereković i sur.: Kompleksnost kao nosilac preferencija i indikator posjećenosti parkova

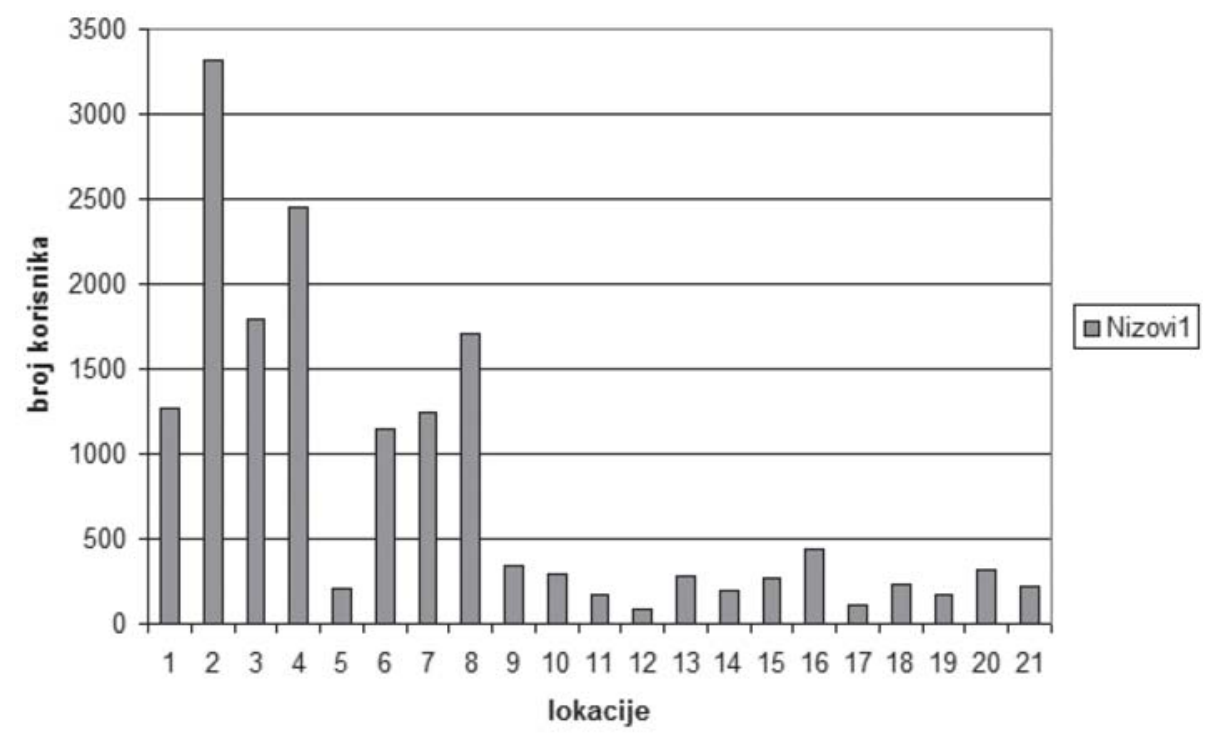

Grafikon 2. Ukupan broj zatečenih korisnika na lokacijama parka Bundek

Graph 2 Observed locations rated according to the total number of registered users Bundek

\section{Rezultati anketnog istraživanja u parku Bundek i parku Velika Gorica}

Mišljenje ispitanika o mogućnosti većeg broja elemenata parkova i njihovom mogućem smještaju.

U parku Velika Gorica podatci pokazuju da $68,9 \%$ ispitanika podupire ideju da se poveća broj parkovnih sadržaja, a ostalih $31,1 \%$ ispitanika odbacuje takvu ideju. Nadalje, ispitanici koji smatraju da treba povećati broj sadržaja, u najvećem postotku smatraju da te sadržaje treba smjestiti u najmanje složeni dio parka. Prema rezultatima izrazito je mali postotak ispitanika koji smatra da je u parku Bundek dovoljno sadržaja (15,9\%) naspram $84,1 \%$ ispitanika koji smatra da je potrebno povećati sadržaje. Nadalje, od onih ispitanika koji to smatraju potrebnim najviše njih $(43,0 \%)$ smatra da je potrebno povećati sadržaje upravo $\mathrm{u}$ istočnom, najmanje složenom dijelu parka 
Mišljenje ispitanika o vrsti elemenata koje je potrebno povećati u parkovima.

U parku Velika Gorica ispitanicima najviše nedostaju društveni sadržaji (šah, boćanje, sprave za vježbanje i sl.), koji se svrstavaju u funkcionalne, aktivne parkovne sadržaje. Za tu se skupinu sadržaja opredijelilo $36,7 \%$ ispitanika, a za sve ostale ponuđene sadržaje ujednačeno je opredjeljenje ispitanika $\mathrm{i}$ to u postocima od $12 \%$ do $19,3 \%$. Takav podatak upućuje na to da u parku zapravo nema sadržaja koji ispitanicima izrazito nedostaju te ako bi se parku povećavao broj sadržaja, to bi trebali biti društveni sadržaji koje ubrajamo $\mathrm{u}$ funkcionalne, aktivne parkovne sadržaje. U parku Bundek, prema dobivenim podatcima, ispitanicima najviše nedostaju sljedeći sadržaji: ekipni sportovi (košarka, nogomet, badminton i sl.) u 44,4\% slučajeva te društvene igre (šah, boćanje, sprave za vježbanje i sl.) u $35,1 \%$ slučajeva. Sve navedene elemente koje ispitanici smatraju nedostatnima ubrajamo upravo u tipične funkcionalne elemente krajobraza.

Procjena fotografija različitog stupnja kompleksnosti.

S obzirom na to da su rezultati procjenjivanja fotografija za oba izdvojena parka vrlo slični prezentirat ćemo ih samo tablično (tablice 3-6) a u nastavku teksta prezentirat ćemo skupne rezultate procjene fotografija. Zajednički pokazatelji procjenjivanja fotografija ispitanika oba parka prikazani su grafikonima 3-10 u kojima je vidljiva krivulja distribucije odgovora.

Prema rezultatima, fotografija koja najbolje ilustrira park u kojem bi ispitanici provodili slobodno vrijeme je ona s velikim i raznolikim brojem elemenata pri čemu se smanjenjem složenosti smanjuje i privlačnost scena parkova za ispitanike. S druge strane, odgovori ispitanika o tome koja od ponuđenih fotografija djeluje najmanje poticajno za boravak u parku pokazuje da su ispitanicima najmanje složene fotografije niza zapravo i najmanje poticajne za boravak. Ipak, ako pogledamo grafove 4, 6, 8 i 10 (procjena najmanje poticajne fotografije u parku) uvidjet ćemo da su ti podatci dosljedni i prate linearan pad od prve do četvrte fotografije niza, a odstupanje od takve distribucije odgovora zabilježeno je kod pete, najviše složene fotografije niza. Iako nije riječ u velikom postotku ispitanika koji su odabrali takav odgovor (6,6-11,3\%), u ovom slučaju nemamo dosljedan i linearan pad vezan uz smanjenje složenosti i poticajnosti takva parka za boravak, nego imamo "krivulju". Ona upućuje na blagu indikaciju povećavanja broja ispitanika koji vrlo veliku razinu složenosti vide kao neugodnu ili manje ugodnu u odnosu na prethodnu fotografiju niza te je ocjenjuju manje poželjnom u odnosu na prethodnu fotografiju niza. 
Petra Pereković i sur.: Kompleksnost kao nosilac preferencija i indikator posjećenosti parkova

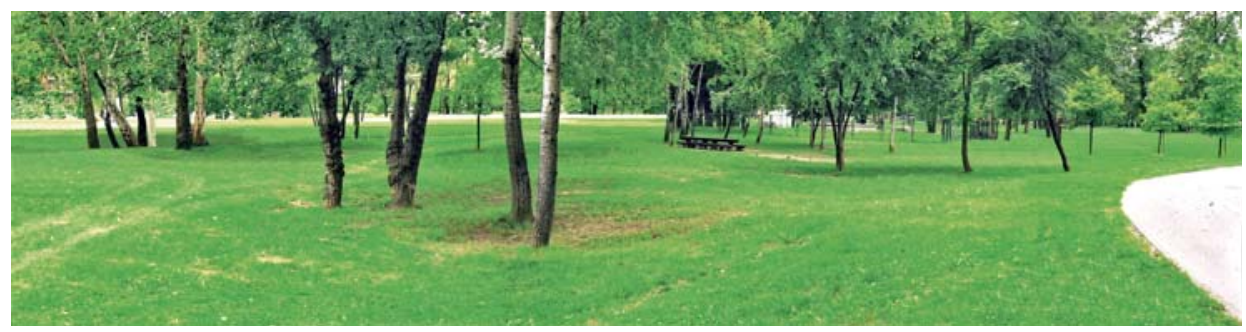

1 Vrlo mala složenost - fotosimulacija.

1 Very low complexity - photo simulation

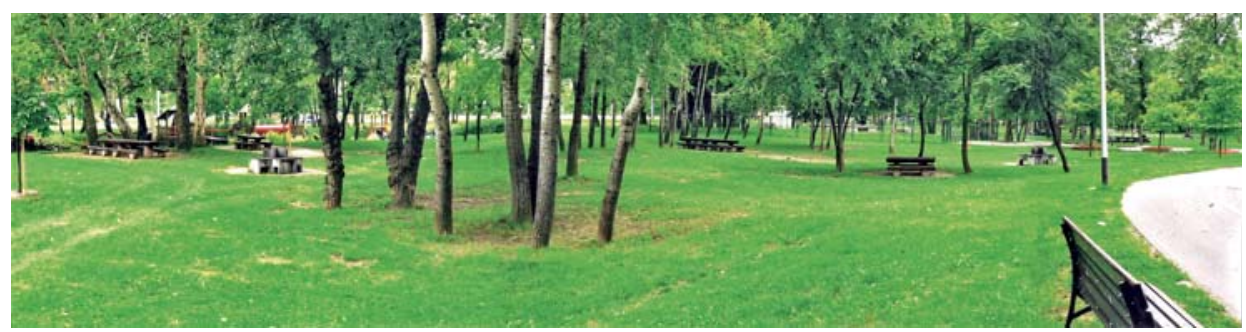

3 Srednja ili umjerena složenost - fotografija postojećeg stanja.

3 Intermediate or moderate complexity - photo of the current state of the location

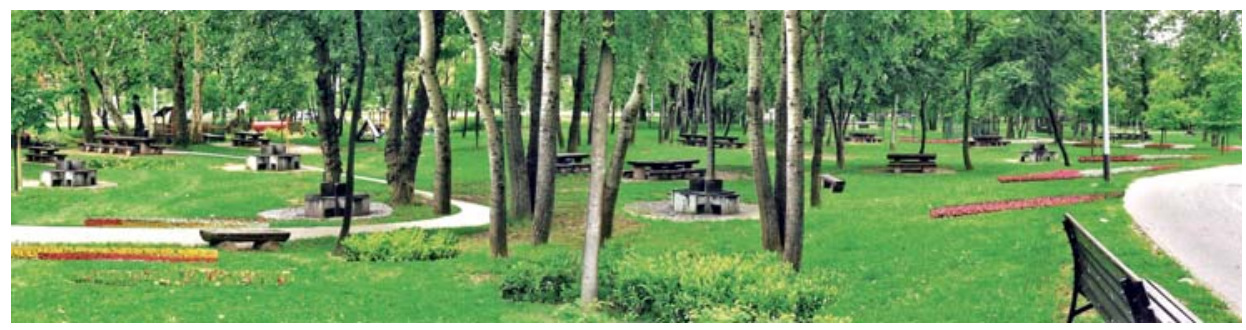

5 Vrlo velika složenost - fotosimulacija

5 Very high complexity - photo simulation

Niz fotografija 1. Primjer pojedinih fotosimulacija korištenih u anketi (park Bundek)

Photo sequence 1 Example of the photo simulation used in the survey (Bundek Park) 
Te podatke smatramo vrlo važnima jer pokazuju da je fotografija 5 , dakle najviše složena fotografija niza, dosegnula onu razinu složenosti koja većem dijelu ispitanika počinje izazivati neugodne konotacije u odnosu na ispitanike koji su se odlučivali za manje složenu fotografiju niza. Dakle, ta bi razina složenosti krajobraza mogla upućivat na onaj stupanj (granicu) kad se složenost više ne primjećuje kao pozitivna karakteristika krajobraza. Na toj granici bi za neki krajobraz mogli reći da ne bi smio biti složeniji nego što već je (ili čak da je dovoljno složen). Usto je vidljivo kod pete fotografije niza B da se taj podatak mogao naslutiti i kod ocjena najviše poticajne fotografije za boravak u parku (grafikon 5), gdje je uobičajeni linearni tok krivulje odnosno povećanja preferencija sa složenošću krajobraza pokazao smanjene preferencije onih koji se odlučuju za fotografiju 5 u usporedbi s onima koji se odlučuju za fotografiju 4. Nadalje, da je u procjeni fotografije 5 upravo posrijedi složenost koja daje naslutiti neke negativne konotacije vezane uz količinu sadržaja iskazali su i ispitanici koji su fotografiju 5 komentirali riječima: "prenapučena je", "previše je", "ovo mi je too much", "previše gust", "ovdje je previše", "prenatrpano je", "pregusto je", "prenaporna je". Uz te podatke važno je napomenuti da vjerujemo da se pri oblikovanju parkova zapravo ne treba odlučivati između dva tipa parka ili situacije 1 i 5, nego parkovno oblikovanje može uključivati i situaciju 1 i situaciju 5, s obzirom na to da uključivanje "i jednog i drugog" zapravo pridonosi ukupnom povećanju složenosti parka. Osim navedenog, iz istih setova fotografija ispitanici su trebali odabrati fotografiju svakog pojedinog niza koja je prema njihovu mišljenju najviše kompleksna ("posjeduje najveći broj i raznolikost ili bogatstvo elemenata"). Rezultati pokazuju da su ispitanici petu fotografiju svakog niza prepoznali kao najviše složenu - u nizu A 99,3\% ispitanika, u nizu B 98,6\%, u nizu C 93,8\%, te u nizu D 97,2\% ispitanika. $\mathrm{S}$ obzirom na to možemo zaključiti da ispitanici imaju jasnu sliku o tome što bi moglo predstavljati najsloženiji krajobraz te da je ta procjena u skladu $\mathrm{s}$ "matematičkim" izrazom i ekspertnom procjenom složenosti (barem kad je posrijedi ovakav tip prezentacije krajobrazne složenosti). 
Petra Pereković i sur.: Kompleksnost kao nosilac preferencija i indikator posjećenosti parkova

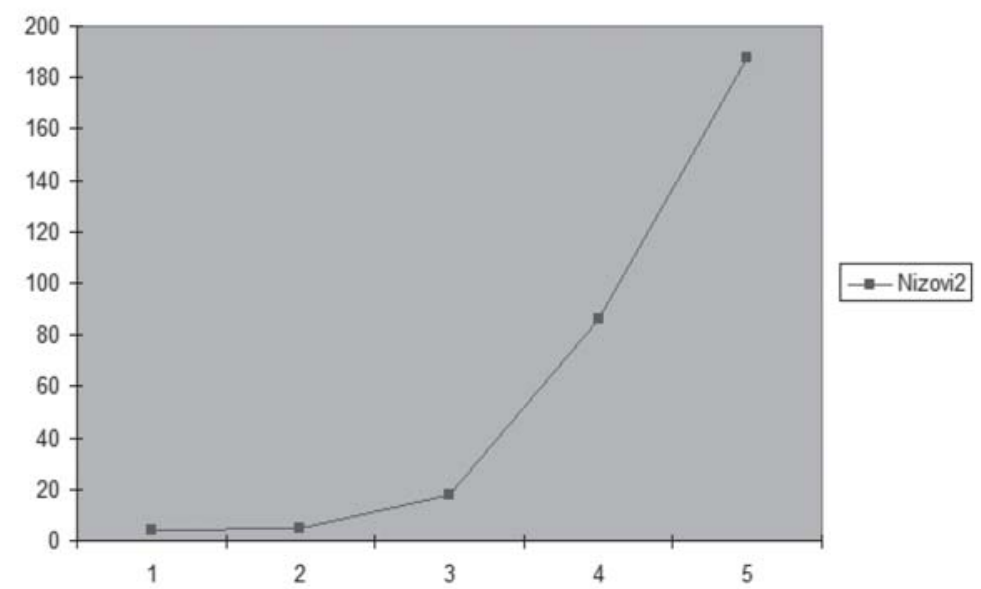

Grafikon 3. Odgovori ispitanika o fotografiji iz niza A koja djeluje najviše poticajno za boravak

Graph 3 Responses regarding the photo from photo sequence A which appears most stimulating for spending free time

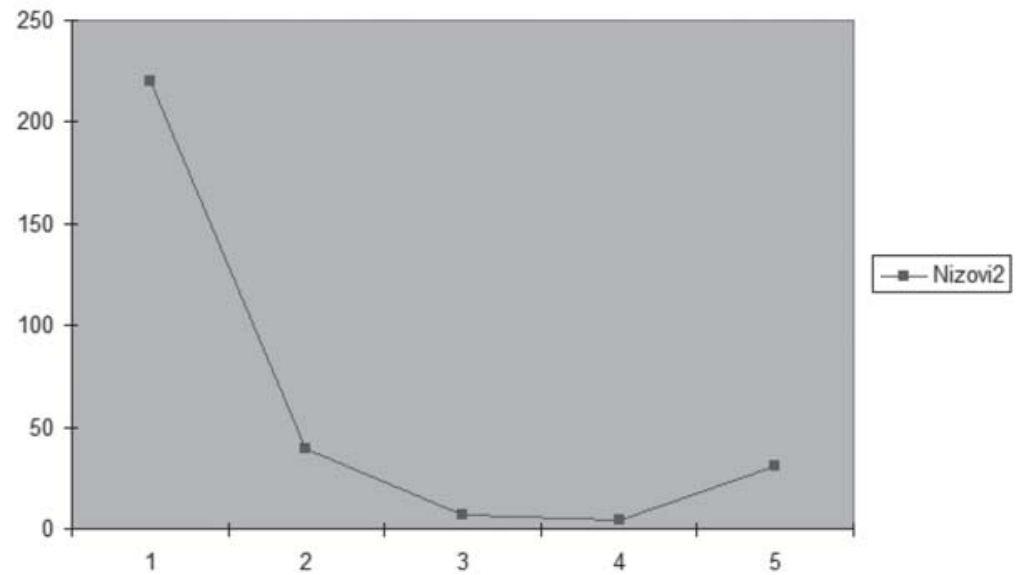

Grafikon 4. Odgovori ispitanika o fotografiji niza A koja djeluje najmanje poticajno za boravak

Graph 4 Responses regarding the photo from photo sequence A which appears least stimulating for spending free time 
Petra Pereković i sur.: Kompleksnost kao nosilac preferencija i indikator posjećenosti parkova

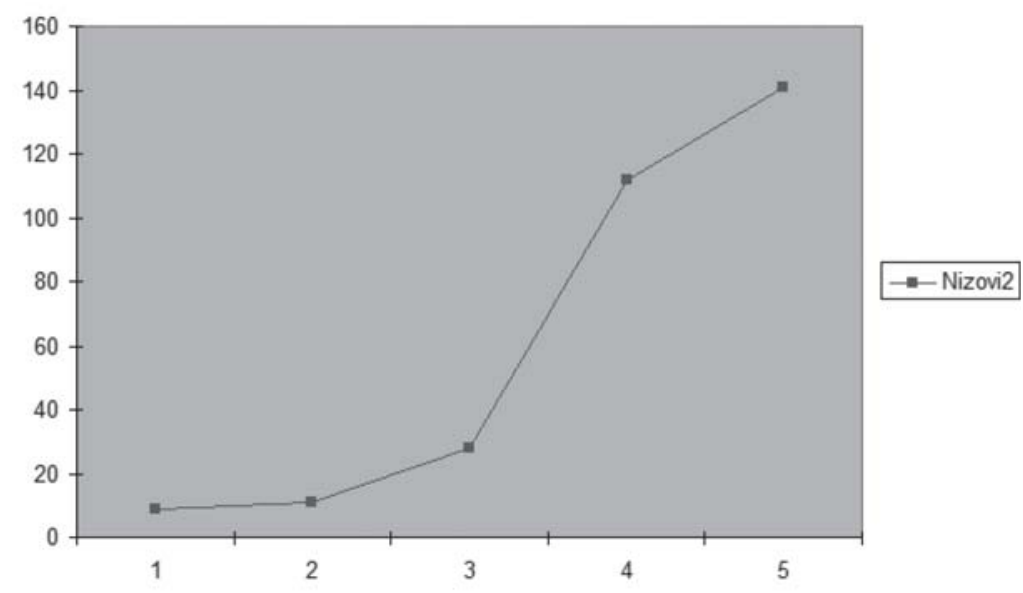

Grafikon 5. Odgovori ispitanika o fotografiji iz niza B koja djeluje najviše poticajno za boravak

Graph 5 Responses regarding the photo from photo sequence B which appears most stimulating for spending free time

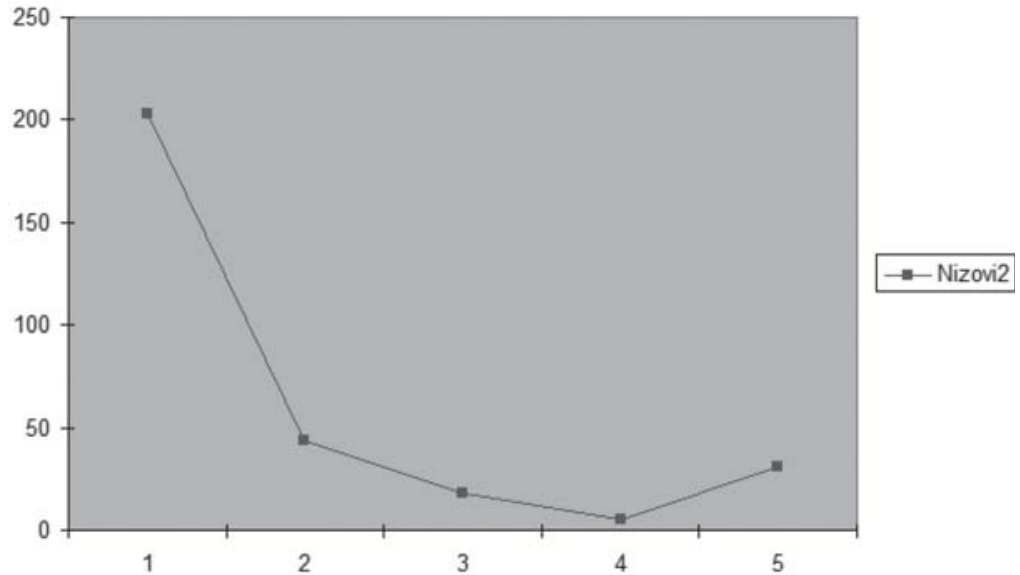

Grafikon 6. Odgovori ispitanika o fotografiji iz niza B koja djeluje najmanje poticajno za boravak

Graph 6 Responses regarding the photo from photo sequence B which appears least stimulating for spending free time 
Petra Pereković i sur.: Kompleksnost kao nosilac preferencija i indikator posjećenosti parkova

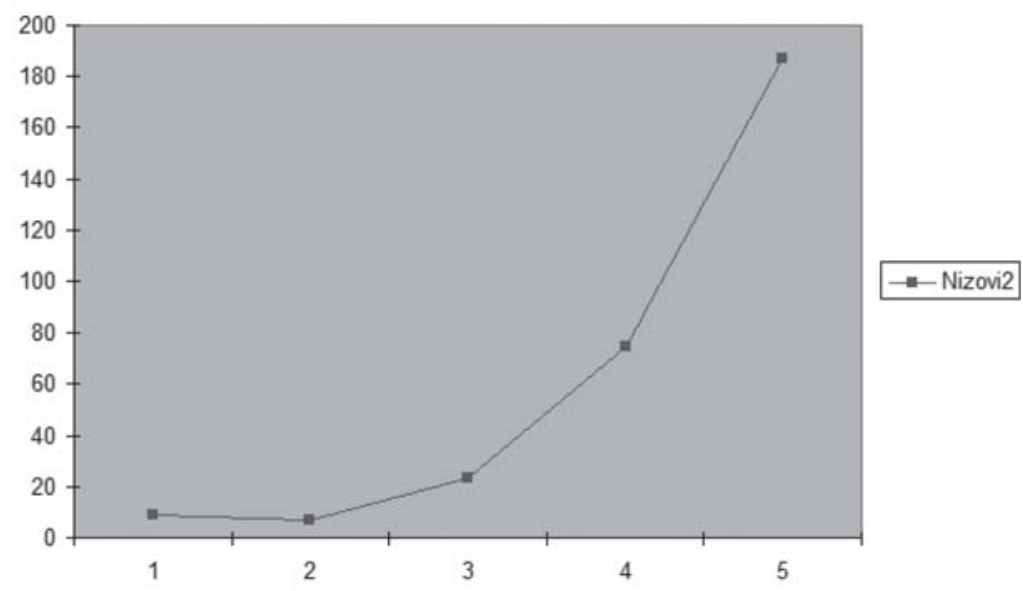

Grafikon 7. Odgovori ispitanika o fotografiji iz niza C koja djeluje najviše poticajno za boravak

Graph 7 Responses regarding the photo from photo sequence $C$ which appears most stimulating for spending free time

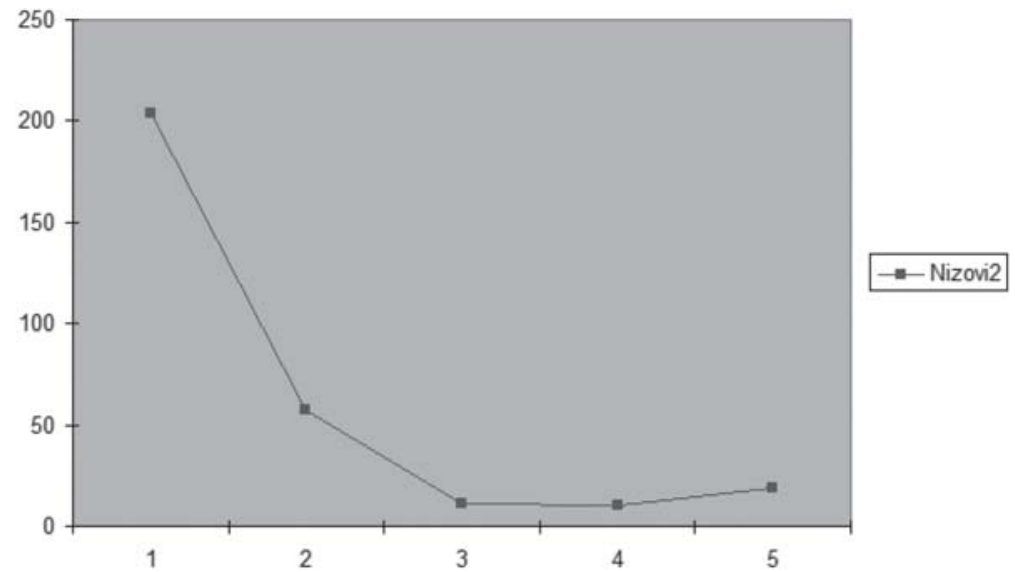

Grafikon 8. Odgovori ispitanika o fotografiji iz niza C koja djeluje najmanje poticajno za boravak

Graph 8 Responses regarding the photo from photo sequence $C$ which appears least stimulating for spending free time 
Petra Pereković i sur.: Kompleksnost kao nosilac preferencija i indikator posjećenosti parkova

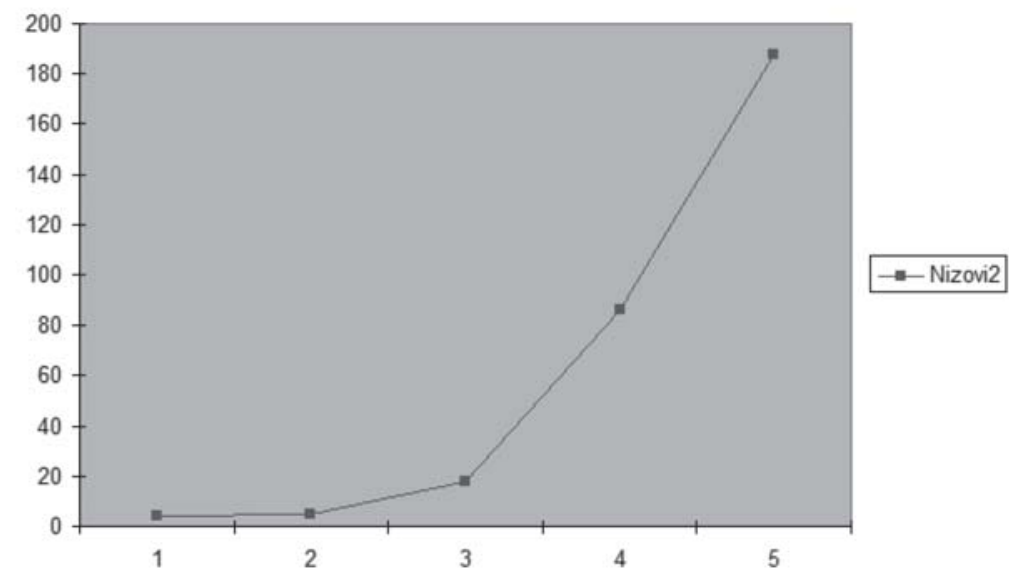

Grafikon 9. Odgovori ispitanika o fotografiji iz niza D koja djeluje najviše poticajno za boravak

Graph 9 Responses regarding the photo from photo sequence D which appears most stimulating for spending free time

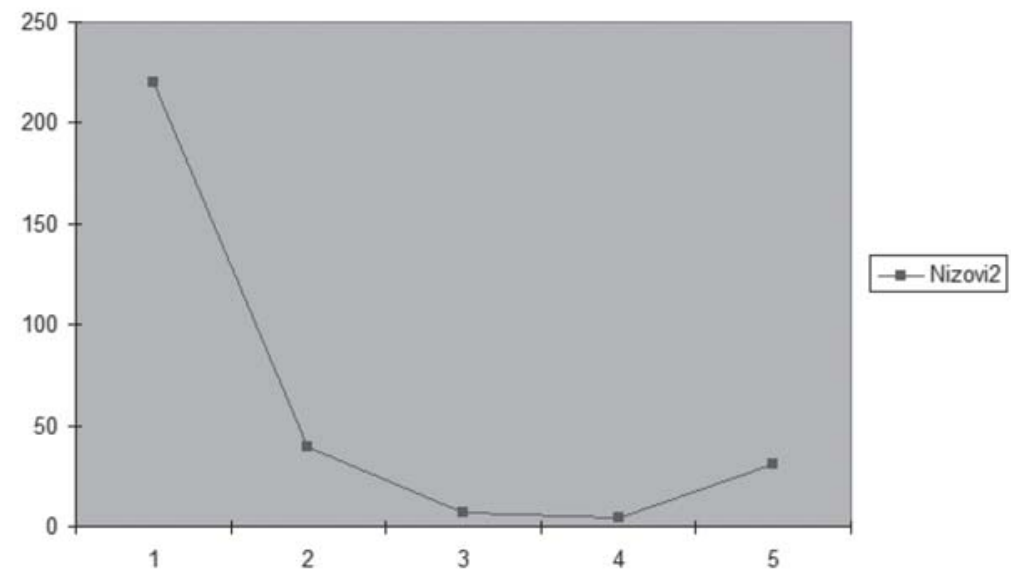

Grafikon 10. Odgovori ispitanika o fotografiji niza D koja djeluje najmanje poticajno za boravak

Graph 10 Responses regarding the photo from photo sequence D which appears least stimulating for spending free time 
Petra Pereković i sur.: Kompleksnost kao nosilac preferencija i indikator posjećenosti parkova

\section{Rezultati istraživanja primjenom metode promatranja}

Ovi rezultati odnose se na primijećene promjene ponašanja ili posjećenosti na lokacijama koje su bile posljedica unošenja, prenošenja, nestanka ili drugih "događanja" u vezi s dinamičnim ili temporalnim dimenzijama složenosti parkova. Tijekom četveromjesečnog promatranja na nekim je dijelovima parkova primijećena velika dinamika raznolikog ponašanja upravo uvjetovana rasponom potencijalnih korištenja odnosno karakteristike višefunkcionalnosti krajobraznih elemenata. Smatramo da su upravo te karakteristike elemenata pridonijele i većoj posjećenosti određenih dijelova parkova. Višefunkcionalnost je u parku Bundek najočitija na primjeru središnjeg jezera, koje je, ovisno o razdoblju i trenutku promatranja, promijenilo višestruke funkcije - odmorište (sjedenje), rekreacija, šetalište, sunčalište, kupalište, plovilište, ribnjak, „neformalno igralište“, konzumacija hrane i pića i dr. Upravo na tome primjeru do izražaja dolazi važnost funkcionalne složenosti jer kad bi promatrali samo vizualnu složenost središnjeg jezera, mogli bi se reći da je obala središnjeg jezera zapravo male složenosti, čak manja i od vizualne složenosti jezera zapadnog dijela parka koji je izrazito manje posjećen. Višefunkcionalnost se može promatrati i kroz pojedine elemente korištene pri oblikovanju krajobraza. Primjerice, vidljiva je i velika razlika u broju aktivnosti i korištenju „običnih“ klupa s naslonom te klupa sa stolovima. Lokacije koje su opremljene jedino pojedinačnim klupama služe uglavnom kako bi se na njima sjedilo, dok se klupe sa stolovima raznoliko koriste - učenje, kartanje i društvene igre, druženje većih skupina ljudi, čitanje, prehrana, proslave, rješavanje križaljki i slične aktivnosti.

Značajna opservacija u parku Bundek bile su privremene "instalacije" postavljene na krajnjoj zapadnoj livadi parka kao predstavnici unošenja privremenih elemenata $\mathrm{u}$ krajobrazne osnove. Specifičnost tog događanja sadržana je u tome da su kugle, inače lagane za kotrljanje i premještanje, postale spontana "igraonica na otvorenom" za sve uzraste posjetitelja parka pri čemu su igre i premještanja navedenih instalacija zabilježene u svim danima opservacija do njihova uklanjanja. Važnost je takva događanja u dvjema činjenicama: jedna je intenzivna interakcija i zanimanje korisnika parka za privremeno unesene elemente, a druga je da je prostor na koji su smještene instalacije, zapravo dio lokacije koja se od svih promatranih lokacija parka Bundek pokazala najmanje posjećenom u vrijeme kada instalacije nisu bile smještene na njoj. 
Nefiksirani krajobrazni elementi također su se pokazali kao uspješni nosioci povećanja funkcionalne krajobrazne složenosti tako da omogućuju prenošenje, smještanje i grupiranje elemenata kakav je u pojedinom trenutku poželjan korisniku tog elemenata. Primjerice, nefiksirani elementi za sjedenje (ležaljke, „ligeštuli“) mogu se premještati radi izdvajanja od drugih korisnika parka odnosno osamljivanje, suprotno tome, za okupljanje više ljudi - druženje, traženje hladovine za sunčanih dana ili smještanje na sunčane položaje, odabir željenih vizura i drugih obilježja parka ili ugođaja. Važnost uloge takvih elemenata $u$ ovom istraživanju vidljiva je na svim lokacijama parka Bundek na kojima elementi nisu fiksirani (nefiksirane klupe i ležaljke) pri čemu je primijećena tako velika dinamika promjena da se i u roku od samo jednog dana raspored nekih elemenata potpuno izmijenio.

U vrijeme opservacija primijećen je povećan broj aktivnosti uvjetovan interakcijom korisnika sa životinjama i biljem. Zabilježene interakcije ovoga tipa nisu velika intenziteta ali su svakako važan dio povećanja aktivnosti (funkcija) određenih dijelova parkova. Pri tome, šetnja kućnih ljubimaca čini dominantnu aktivnost korisnika istočnog dijela parka Bundek (intenzitet posjećenosti tog dijela parka vjerojatno bi znatno odstupao od zabilježenog kad bi i u njemu bio reguliran način šetnje pasa kao što je to u ostalim dijelovima parka). Osim toga, u zapadnom dijelu parka Bundek događanje koje odstupa od uobičajenih aktivnosti šetnje i sjedenja je interakcija sa životinjama (promatranje i hranjenje patka i drugih životinja na jezeru ili suprotno tome ribolov). Ponašanje ljudi različito od uobičajenog uvjetovalo je i dozrijevanje plodova jestivog bilja u parku pri čemu su se primarno šetači zapadnog dijela parka Bundek često preuzimali ulogu sakupljača i konzumenata plodova. Takva su ponašanja, u ovome slučaju, vezana za temporalnu dimenziju složenosti krajobraza uvjetovanu sezonskim promjenama bilja (cvatnja bilja, dozrijevanje plodova, posebice onih jestivih).

Organizirana događanja nedvojbeno utječu na izraziti rast posjećenosti parkova. Međutim, i manja ili gotovo sva druga događanja poput likovne radionice, dječjeg festivala, vježbanja na otvorenom, izložba na otvorenom, unos ,štandova“ i konstrukcija i sl. pokazala su da u manjoj ili većoj mjeri utječu na povećanu posjećenost parkova ili nekih njegovih dijelova. Jedan od najočitijih primjera je održavanje likovne radionice u parku V. Gorica koja je ukupno gledajući najmanje posjećenu lokaciju parka, u vrijeme održavanja radionice, pretvorila se u najposjećeniji dio parka. 
Petra Pereković i sur.: Kompleksnost kao nosilac preferencija i indikator posjećenosti parkova

Privremeni elementi koje unose korisnici parka. Specifičnost je ovih podataka u iznenađujuće veliku broju zabilježenih privremenih elemenata koje posjetitelji unose u park Bundek. Relativno velik udio unesenih sadržaja, pogotovo onih koje svrstavamo u klasični parkovni inventar (strukture za sjedenje i ležanje, sportski sadržaji poput mreža ili terena za badminton i odbojku), upućuje na to da korisnicima neki sadržaji nedostaju te da je moguće, čak i poželjno, povećati broj elemenata i to upravo onih aktivnih, funkcionalnih elemenata.

\section{RASPRAVA}

Primjena koncepta složenosti važan je čimbenik uspješnosti oblikovanja otvorenih prostora, a do takva zaključka dolazimo prateći rezultate ovog rada. Oni upućuju na to kako se, ovisno o promjenama u razinama i dimenzijama složenosti, mijenja intenzitet i korištenje prostora kao što se mijenjaju i njegove vizualne procjene. Time je, s jedne strane, utvrđeno da su složeniji dijelovi parkova posjećeniji od manje složenih dijelova parkova kao i da ponašanje korisnika varira ovisno o dinamičnim pokazateljima složenosti. S druge strane, pokazalo se kako su i vizualne procjene u skladu s tim, odnosno, da su složenije scene uvijek iskazane kao situacije u kojima bi ispitanici radije provodili vrijeme nego što bi to u manje složenim scenama. Važno je naglasiti da je istraživanjem (anketom) ustanovljen stav ispitanika kako je u parkove najpotrebnije unijeti sadržaje upravo funkcionalnoga karaktera (osobito onih aktivnoga karaktera) odnosno važnim se smatra povećanje funkcionalne složenosti krajobraza.

I u drugim je istraživanjima složenost izdvojena kao važna odlika krajobraza i otvorenih prostora (Kaplanovi 1998. i 1989.; Stamps, 2004.; Herzog i Bryce, 2007.). Štoviše, Tveit i sur. (2006.) složenost izdvajaju kao jedan od devet ključnih vizualnih koncepata koji su se istraživali i potvrdili u vezi s krajobrazima. Neka istraživanja toga tipa proveli su De Val i sur. (2006.), Simonič (2006., 2003.), Pereković i sur. (2007.) koji također složenost izdvajaju kao važan čimbenik preferencija krajobraza. Iako se složenost krajobraza unutar toga uglavnom istraživala kao vizualan koncept, moguće je pronaći istraživanja koja pokazuju povećanje broja korisnika u vezi s povećanjem nekih određenih grupa sadržaja. Tako, primjerice, Bedimo Rung i sur. (2005.) napominju da široka raznolikost sadržaja može uzrokovati različite tipove korištenja okoliša te da postojanje ili izostanak različitih prostornih atributa može biti važna 
odrednica sposobnosti otvorenih prostora da potiču fizičke aktivnosti i aktivnosti odmora. Nadalje, Bull (2007.) ističe kako se tamo gdje postoje neka urbana obilježja, među ostalim i miješano korištenje prostora, povećava vjerojatnost viših razina participacije korisnika. Slično je istraživanje Ghela (2007.), koji utvrđuje kako novi sadržaj i različite aktivnosti mogu intenzivirati javni gradski život i korištenje prostora.

S obzirom na navedeno i rezultate koji su pokazali važnost funkcionalnih dimenzija složenosti, otvoreni prostori ne bi smjeli biti niti analizirani niti vrednovani samo u vizualnom smislu, a time ni promatranje njihove složenosti ne bi smjelo biti jednostrano odnosno samo vizualno (analiziranje složenosti koje se fokusira samo na vizualne aspekte složenosti daje samo jedan aspekt složenosti). Jednako tako, ako bismo "funkcionalni" fokus složenosti primijenili, primjerice, u strukturnim analizama složenosti tako da uz vizualne i funkcionalne elemente prihvaćamo i sve moguće funkcije izdvojenih elemenata, baza ove procjene i kategorizacije dodatno bi se i uvelike proširila. Stoga je zaključak da se funkcionalna i vizualna složenost mogu pratiti kao dvije odijeljene složenosti krajobraza, no ako se želi govoriti o nekoj ukupnoj ili cjelovitoj složenosti nekog tipa oblikovanoga krajobraza, tad se ove dvije dimenzije moraju susretati u nekom usporednom prikazu.

Također, svaki oblikovani krajobraz, uza svoje statične elemente složenosti koji se mogu prihvatiti izdvajanjem elemenata vizualnog i funkcionalnog (ili višefunkcionalnoga) karaktera, ima i dinamičnu dimenziju složenosti, koja se također u ovom istraživanju pokazala važnom za korištenje otvorenih prostora. Time dolazimo zapravo do višedimenzionalne složenosti oblikovanih krajobraza koja $\mathrm{s}$ jedne strane, $\mathrm{u}$ istraživačkom smislu, obvezuje na višedimenzionalno poimanje i razmatranje složenosti $u$ istraživanjima, a $s$ druge strane, u projektantskom smislu, obvezuje na rješenja koja su suočena s problemom koncepta višedimenzionalne složenosti u svojem izrazu i vrednovanju. Naglašavanje te dimenzije složenosti otvorenih prostora pronalazimo i kod drugih autora (Heft, 1998.; Purcell i sur., 2001.; Papadimitriou, 2002.; Witt i sur., 2005.; Aspinall i sur.; 2007.; Heft, 2007.; i dr.), te su sukladni s konceptom "prostorne priuštivosti" (eng. affordance), koji u percepcijskim procjenama okoliša daje osobitu važnost funkcionalnim obilježjima krajobraza ili krajobraznih elemenata. 
U ovom radu pokušalo se odgovoriti i na pitanje "koliko je složen krajobraz dovoljno složen krajobraz". Dosadašnja istraživanja stvorila su prije navedeni općeniti stav koji zagovara složenije krajobraze od manje složenih, no ako se ovo pitanje postavi u okvire stupnjevanja ili stalne složenosti od male preko srednje do velike složenosti, otvara se još jedno područje koje je predmet diskusija različitih autora. Pri tome se uglavnom smatra da je stanje male složenost nepovoljno (nije preferirano), ali i da zapravo postoji i stanje tako velike (može se reći prevelike) složenosti u kojem se složenost počinje percipirati kao nepovoljno ili neprivlačno stanje. Stoga se smatra da je ljudima ugodno primati informacije u određenim omjerima pri čemu premalo informacija producira senzornu deprivaciju, a previše informacija stvara senzorno preopterećenje (Rapoport, u Ewing i sur., 2005.). Pri tome se mnogi autori koji se bave kompleksnošću (Kaplan i Kaplan, 1972.; McCarthy, 1979.; Nasar, 1994.; De Val, 2006.; Roberts, 2007.; Ode i sur., 2010.; i dr.) pozivaju na Berlyneov rad iz 1963. i/ili Wohlwillov iz 1976. koji iskazuju da se više cijene srednje razine kompleksnosti nego jednostavne ili visokokompleksne stimulacije odnosno da postoji ona razina kompleksnosti nakon koje prednosti opadaju (obrnuta "U" distribucija).

U ovom istraživanju i pokušaju odgovaranja na pitanje "koliko je složen krajobraz dovoljno složen krajobraz" dobiveni su sljedeći rezultati. I park Bundek i park Velika Gorica, prema ekspertnoj analizi strukturne složenosti, parkovi su srednje razine složenosti (neprekidno od male, srednje do velike složenosti). Rezultati anketnog istraživanja pokazali su da većina ispitanika smatra da parkovi nisu dovoljno složeni odnosno poduprli bi povećanje količine sadržaja u parkovima. U procjenama različito složenih scena parkova podaci pokazuju kako su ispitanicima u odnosu na postojeće stanje privlačnije parkovne situacije s povećanim razinama elemenata oblikovanja. Pri tome su ispitanicima najmanje složene fotografije zapravo i najmanje poticajne za boravak, a fotografija postojećeg stanja koja je ujedno predstavljala umjerenu razinu složenosti, ni u jednom slučaju nije odabrana kao najviše poticajna za boravak u parku. Na temelju toga možemo zaključiti da srednja, umjerena ili postojeća razina složenosti nije najomiljenija, nego je to velika složenost. S druge strane, iskazani podaci procjene fotografija indiciraju blag porast onih ispitanika kojima je najsloženija fotografija niza najmanje poticajna za boravak u parku. Iako nije riječ o velikom postotku ispitanika koji su odabrali takav odgovor, podatak upućuje na to da nemamo ujednačen linearan pad odabira kompleksnosti i prednosti te da se u jednoj točki linearnog pada povećava broj 
ispitanika koji visoku razinu složenosti vide kao nepoticajnu ili manje poticajnu za boravak u parku. Dakle, ta bi razina složenosti krajobraza mogla upućivati na onaj stupanj (granicu) složenosti kad se ona više ne primjećuje kao pozitivna karakteristika krajobraza te kad bi za neki krajobraz mogli kazati da ne bi smio biti složeniji nego što već jest (ili čak da je dovoljno složen!). Iako ovi podatci daju blagu indikaciju, smatramo ih važnima jer s jedne strane upućuju i na to da srednje razine složenosti nisu najomiljenije nego da se prednost daje velikim razinama složenosti. S druge strane, pokazuju kako ipak postoji "optimalna" razina složenosti odnosno ona granica kad se kompleksnost počinje gledati kao neugodna ili, možemo reći, kad postaje prevelika. To ujedno znači da ovo istraživanje daje blagu indikaciju postojanja obrnute „U“ distribucije prednosti ali se pritom ne bi lako nadovezali na dosadašnje rezultate $i$ to iz nekoliko razloga koje ćemo objasniti u nastavku teksta.

Prvo, smatramo da je u istraživanjima posebice važno pitanje neprekidnosti ili stupnjevanja složenosti. Smatramo to bitnim jer, ako je taj kontinuum nedorečen, moguće je uspoređivati dva ili više krajobraza prema složenosti, ali ne i doći do konsenzusa o pitanju male, srednje i velike ili prevelike složenosti. Pri tome, stanje minimalne razine složenosti prilično je jasno ("prazan" krajobraz ili ono što je zapravo i najčešće početak svakoga oblikovanog prostora - prazna ploha), no problematične su njegove gornje ili maksimalne razine složenosti. Dakle, je li to krajobraz koji je potpuno popunjen elementima ("više ne stane") ili je to krajobraz koji je ipak zadržao koherentnost i ne nalikuje na kaotičan krajobraz (neuredan ili nelogičan, dakle krajobraz koji je izgubio koherentnost)? To pitanje smatramo jednako bitnim kao pitanje određivanja indikatora koji bi mogli upućivati na složenost pojedinih oblikovanih otvorenih prostora ili krajobraza, a time objašnjavamo i neujednačenosti rezultata dosadašnjih istraživanja koja su se bavila krajobraznom složenošću (uz razlike koje nalazimo i u indikatorima krajobrazne složenosti). U ovom istraživanju minimalne i maksimalne razine složenosti uzete su u obzir u odnosu na postojeće stanje krajobraza pri čemu minimalne razine nisu značile ni potpunu ispražnjenost krajobraza ni potpunu popunjenost, no na tome području svakako vidimo izazov za neka buduća istraživanja $s$ obzirom na to da, ako ne postoji konsenzus o neprekidnoj složenosti, ne postoji ni osnova za analizu stupnja složenosti različitih oblikovanih otvorenih prostora. U tome vidimo i razloge odstupanja ovog istraživanja od onih koja zagovaraju umjerene razine složenosti. 
Petra Pereković i sur.: Kompleksnost kao nosilac preferencija i indikator posjećenosti parkova

ZAKLJUČAK

U ovome radu istraženi su određeni aspekti vezani uz važnost i konceptualizaciju fenomena složenosti u oblikovanju otvorenih javnih prostora. Dobivene spoznaje mogu se sažeti sljedećim zaključcima:

Veća složenost određenih dijelova parkova u odnosu na manje složene dijelove znači i njihovu veću posjećenost. Isto pokazuju i vizualne procjene ispitanika - više se vole stanja velike ili povećane složenosti nego stanja male složenosti ili postojeća stanja parkova koja su umjerene složenosti. S obzirom na navedeno, jasno je da je koncept složenosti važna komponenta oblikovanja i uspješnosti otvorenih prostora.

Pri definiranju i procjenama složenosti otvorenih prostora veliku važnost ima odabir indikatora i kriterija koji su se pri tome koristili. Cjelovito praćenje složenosti oblikovanih krajobraza treba okupljati vizualne i funkcionalne indikatore složenosti (dobivene fizičkom raščlambom krajobraza) te dinamične indikatore složenosti (dobivene izdvajanjem dinamičnih dimenzija krajobraza). Parcijalni ili djelomični indikatori i kriteriji krajobrazne složenosti koji ne obuhvaćaju navedene indikatore (vizualne, funkcionalne, dinamične) prezentiraju i parcijalne procjene, i parcijalna vrednovanja složenosti.

Kalkulacije složenosti otvorenih prostora, osim ujednačenog definiranja i navedenih indikatora, trebaju prihvatiti opće baze stupnjevanja krajobrazne složenosti koje bi pri procjenama oblikovanih krajobraza dale ujednačene temelje za njihovu usporedbu.

Značenje raspona od jednostavnosti do kompleksnosti strukture treba kvalificirati kao stanja male, srednje, velike i prevelike složenosti, kao što je i potreban konsenzus o određivanju stupnja velike odnosno prevelike složenosti. Pri tome treba skrenuti pozornost na mjerila i/ili dimenzije krajobraza te razlike između krajobraza velikih i malih mjerila, te različitih tipova urbanih krajobraza.

$\mathrm{Na}$ kraju treba istaknuti da je koncept složenosti važan čimbenik oblikovanja otvorenih prostora koji pridonosi njihovoj uspješnosti i kvaliteti, a primjena toga koncepta može $\mathrm{u}$ određenoj mjeri utjecati na povećanu posjećenost i korištenje otvorenih prostora. Pri tome se stanja velike složenosti smatraju optimalnijima nego stanja srednje ili manje složenosti današnjih oblikovanih krajobraza. 
Petra Pereković i sur.: Kompleksnost kao nosilac preferencija i indikator posjećenosti parkova

\section{POPIS LITERATURE:}

1. Aspinall, P. A., Ward Thompson, C., Alves, S., Sugiyama, T., Brice, R. \& Vickers, A. (2007.): Prioritising factors influencing visits to greenspace: conjoint analysis. Open Space: People Space 2. Innovative Approaches to Research Excellence in Landscape and Health. Conference proceedings (pp. 35-39). Edinburgh.

2. Bedimo-Rung, A. L., Mowen, A. J. \& Cohen, D. A. (2005.): The significance of parks to physical and public health. American Journal of Preventive Medicine, 28, pp. 159-68.

3. Fuente de Val, G., Atauri, J. A. \& V. de Lucio, J. (2006.). Relationship between landscape visual attributes and spatial pattern indices: A test study in Mediterranean-climate landscapes. Landscape and Urban Planning, 77, pp. 393-407.

4. Gehl, J. (2007.): Public spaces for a changing public life. Open Space: People Space 2. Innovative Approaches to Research Excellence in Landscape and Health (pp. 3-11). London and New York: Taylor \& Francis.

5. Goličnik, B. (2008.): Parki in njihovi uporabniki. Urbani izziv [Parks and their Users. Urban Challenge], 2, pp. 10-17. Available from: http://urbani-izziv.uirs.si/LinkClick.aspx?fileticket=Ax3BjEkaFV4\%3d\&tabid=131.

6. Heft, H. (1998.): Affordances of children's environments: A functional approach to environmental description. Children's Environments Quarterly, 5, pp. 29-37.

7. Heft, H. (2007.): The participatory character of landscape. Open Space: People Space 2. Innovative Approaches to Research Excellence in Landscape and Health. Conference proceedings (pp. 18-23). Edinburgh.

8. Herzog, R. T. \& Bryce, A. G. (2007.): Mystery and preference in Within-Forest Settings. Environment and Behavior, 39, pp. 779-796.

9. Kaplan, R. \& Kaplan, S. (1989.): The Experience of Nature: A Psychological Perspective. New York: Cambridge University Press.

10. Kaplan, R., Kaplan, S., \& Ryan, R. L. (1998.): With People in Mind. Design and Management of Everyday Nature. Washington, DC: Island Press.

11. Kaplan, S. Kaplan, R. \& Wendt, J. S. (1972.): Rated preference and complexity for natural and urban visual material. Perception \& Psychophysics, 12(4), pp. 354-356.

12. McCarthy, M. M. (1979.): Complexity and valued landscapes. Paper presented at the National Conference on Applied Techniques for Analysis and Management of Visual Resource. Nevada, April 23-25. Available from: http://www.fs.fed.us/psw/publications/documents/psw_gtr035/psw_gtr035_05_ mccarthy.pdf 
Petra Pereković i sur.: Kompleksnost kao nosilac preferencija i indikator posjećenosti parkova

13. Nasar, J. L. (1994.): Urban design aesthetics - The evaluative qualities of building exteriors. Environment and Behavior, 26(3), pp. 377-401.

14. Ode, A., Hagerhall, C. M. \& Sang, N. (2010.): Analysing visual landscape complexity: Theory and application. Landscape research, 35, pp. 111-131.

15. Palmer, J. (2003.): Research Agenda for Landscape Perception. Trends in Landscape Modeling Proceedings at Anhalt University of Applied Sciences. Available from: http://www.masterla.de/conf/pdf/conf2003/52palmer.pdf

16. Papadimitriou, F. (2002.): Modelling indicators and indices of landscape complexity: An approach using G.I.S. Ecological indicators, 2, pp. 17-25.

17. Pereković, P., Aničić, B., Hrdalo, I., Rechner, I., \& Andlar, G. (2007.). Percepcija osnovnih karakteristika otvorenih prostora u stambenim naseljimaprimjer Grada Zagreba i Velike Gorice. Društvena istraživanja [Basic perception characteristic of open spaces in residential areas - for example the City of Zagreb and Velika Gorica. Social Research], 92, pp. 1013-1330.

18. Purcell, T., Peron, E. \& Berto, R. (2001.): Why do preferences differ between scene types? Environment and Behavior, 33, pp 93-106.

19. Roberts, M. N. (2007.): Complexity and aesthetic preference for diverse visual stimuli (Doctoral thesis). Department de Psicologia, Universitat de les Illes Balears.

20. Simonič, T. (2003.). Preference and perceived naturalness in visual perception of naturalistic landscapes. Zb. Bioteh. Fak. Univ. Ljubl., Kmet, 81-2, pp. 369-387.

21. Simonič, T. (2006.): Urban landscape as a restorative environment: Preferences and design considerations. Acta agriculturae Slovenica, 87(2), pp. 325-332.

22. Stamps III, E. A. (2004.): Mystery, complexity, legibility and coherence: A meta-analysis. Journal of Environmental Psychology, 24, pp. 1-16.

23. Tveit, M., Ode, A., \& Fry, G. (2006.): Key concepts in a framework for analysing visual landscape character. Landscape Research, 31, pp. 229-255.

\section{Adresa autora - Author's address:}

doc.dr.sc. Petra Pereković, e- mail: pperekovic@agr.hr prof.dr.sc. Branka Aničić, e- mail: banicic@agr.hr

Sveučilište u Zagrebu, Agronomski fakultet, Zavod za ukrasno bilje, krajobraznu arhitekturu i vrtnu umjetnost, Svetošimunska cesta 25, 10000 Zagreb
Primljeno - received: 15.07.2017. 